\title{
ASPECTOS DE ÉTICA CLÍNICA
}

Las contribuciones recibidas y aceptadas para este número de Acta Bioethica son, dentro de lo misceláneo de su carácter, aportaciones al vasto campo de lo que se llama "ética clínica". Esto es, el comportamiento de los agentes morales en el espacio de pedir y recibir ayuda que se identifica con la voz "clínica". La relación interpersonal es aquí decisiva y si bien es posible conducir estudios empíricos sobre los contextos y las formas, la interioridad de los participantes será siempre objeto de inferencia a partir de la conducta, la palabra o el dato fisiológico.

La institucionalización de las formas de pedir y dar ayuda ha generado profesiones especializadas. No en vano se las llama "profesiones éticas", porque en ellas no basta solo la experiencia, el conocimiento y la destreza. En ellas se da una especial forma de contextualizar todo en relaciones humanas: con aquellos a quienes se sirve; con quienes forman el grupo profesional; con las autoridades que legislan y regulan. Es por eso que lo que diferencia una profesión de un oficio es la existencia de unas normas de conducta que suelen aludirse como códigos de ética, aun cuando existen muchas variedades.

La amplitud del campo semántico interpelado por la voz clínica se refleja en estos trabajos. Los hay que abordan temas relacionados con la comunicación en distintas situaciones derivadas de un diagnóstico o de una condición estructural de los servicios sanitarios. También se aborda el límite del paternalismo, que inevitablemente se asocia históricamente a las profesiones modernas, dirigidas a hacer el bien desde la postura del experto sin necesariamente dar autonomía a quienes se beneficia. Las implicaciones éticas del diagnóstico prenatal son materia de análisis.

En la sección "Interfaces" se incluye una nota sobre la constitución humana y su importancia en la medicina y las ciencias. Es un tema que ocupó a la medicina de los siglos XIX y XX en forma importante. Numerosas tipologías fueron materia de debate. De hecho, la metáfora del cuerpo como res politica llevó a titular "constituciones" aquellos textos que vertebran la vida social y política de las naciones. El constitucionalismo, hoy, está en una curiosa transición conceptual, toda vez que ha sido reemplazado por un "genomicismo" que, en cierta manera, repite la noción de lo estable de lo humano a través de sus mutaciones vitales.

En esta sección se encuentra mencionado también el complejo problema de la retractación o retiro de artículos publicados debido a problemas de replicabilidad o descubrimiento de plagio. La verdad es que este tema es la punta de un iceberg moral, porque involucra toda la cadena de actos y procesos, desde la preparación de los datos, la redacción de los artículos, la evaluación por pares y la decisión editorial. No tenemos alternativas, hoy, para los problemas derivados de la falta de integridad en las publicaciones. A ello se suma el que las pautas éticas intentan universalidad en muchos campos sin considerar las especificidades del trabajo disciplinar. Los conceptos de plagio y de honradez, por paradójico que parezca, son mudables con el tiempo y el lugar. Lo cual exige, en el fondo, una verdadera tarea de crítica cultural e histórica para comprender qué es hoy la investigación.

Otro tema de esta sección, que en el futuro cobrará importancia, es el relativo a la ética del trabajo con animales, sujetos de investigación que no están siempre protegidos en forma adecuada por las normativas en uso. La relación humanidad/animalidad, o mejor humanidad/naturaleza, está en los orígenes mismos del concepto de bioética de Fritz Jahr y no fue ajena a Aldo Leopold y Van Rensselaer Potter. Nuestra vinculación con la naturaleza suele ser depredatoria y destructiva, en estrecha relación con lo humano, que es, en más de una dimensión, el elemento agresivo de la evolución biológica. No hay especie que no haya destruido más el planeta que la humana, en todas sus variedades. 
Como siempre, tenemos artículos destinados a la enseñanza de la bioética. Muchos ensayos curriculares suelen llenar las páginas de las revistas. La mayoría declara triunfos lo que no son sino esperanzas de comportamientos probos en los educandos. Surge la duda de si la educación en ética —no la enseñanza - es algo que debiera tener un lugar como "ramo" o una forma de enseñar toda disciplina desde una perspectiva integral. La experiencia nos vuelve escépticos sobre lo que es éxito o fracaso de las experiencias educativas.

Acta Bioethica continúa siendo un foro amplio. Su edición electrónica es consultada frecuentemente. La versión impresa se conserva en bibliotecas académicas. La única condición para aceptar trabajos es que los evaluadores los consideren meritorios. Posiblemente, se cometen errores pero no son la regla sino la excepción. Por lo demás, muchos de los temas que se debaten en la revista son lo que se dice "opinables" y no tienen soluciones de universal aceptación.

Debemos agradecer al cuerpo de editores y revisores su permanente apoyo. La contribución especial del programa de ética de la Universidad de Miami, a través del profesor Kenneth Goodman, es reconocida y apreciada. La permanente exigencia de los sistemas de registro SciELO y Thomson Reuters, y el sostenido crecimiento del índice de impacto en una revista que pertenece tanto a las humanidades como a las ciencias, obligan al equipo editorial a mantener estándares elevados. Confiamos que el Centro Interdisciplinario de Estudios en Bioética, al alero de la Universidad de Chile, podrá continuar esta labor de promoción y expansión del pensamiento bioético.

Fernando Lolas Stepke 